\title{
Optimization of Ethanol Production from Enzymatic Hydrolysate of Maize Stover
}

Harshvadan Patel ${ }^{1}$, Jyoti Divecha ${ }^{2}$ and Amita Shah ${ }^{1 *}$

${ }^{1} B R D$ School of Biosciences, Sardar Patel Maidan, Satellite Campus, Sardar Patel University, Vallabh Vidyanagar, Gujarat, India ${ }^{2}$ Department of Statistics, Sardar Patel University, Vallabh Vidyanagar, Gujarat, India

\begin{abstract}
For efficient bioethanol production from maize stover, fermentation of glucose and xylose both was attempted using Saccharomyces cerevisiae and Pichia stipitis sequentially from enzymatic hydrolysate of mild alkali treated maize stover. Enzymatic saccharification of mild alkali treated maize stover at high substrate $(30 \%)$ loading using 13.0 FPU/g commercial cellulase (MAPs 450) and $74.42 \mathrm{U} / \mathrm{g}$ crude $\beta$-xylosidase (Inhouse produced) after $36 \mathrm{~h}$, yielded $161.32 \mathrm{mg} \mathrm{ml}^{-1}$ reducing sugars. Ethanol production was optimized employing response surface methodology. Under optimized conditions viz. 5\% glucose, $14.55 \%$ inoculum and Time $35.51 \mathrm{~h} ; 90.65 \%$ glucose was utilized and produced $18.93 \mathrm{~g} \mathrm{l}^{-1}$ ethanol with $0.53 \mathrm{~g} \mathrm{l}^{-1} \mathrm{~h}^{-1}$ productivity by Saccharomyces cerevisiae NCIM 3524 . Further attempts were made to produce ethanol from xylose present in enzymatic hydrolysate using Pichia stipitis NCIM 3497. However, xylose conversion was not satisfactory as only $71 \%$ xylose was utilized.
\end{abstract}

Keywords: Aspergillus niger ADH-11; High substrate saccharification; Response surface methodology; Ethanol; Saccharomyces cerevisiae NCIM 3524; Pichia stipitis NCIM 3497

\section{Introduction}

The progress of bioethanol industries could help to reduce dependence on fossil fuels and moderate global warming [1]. Bioethanol derived from lignocellulose can be a welcome technology due to its sustainability, lower-cost, and significantly larger availability of feedstock reserves as compared to starch-based ethanol [2,3]. Among various types of lignocellulosic biomass, maize stover is observed as one of the encouraging feedstock for the production of cellulosic bioethanol because of its high content of cellulose and hemicellulose [4]. However bioethanol production from lignocellulosic biomass is a challenging process because of its complex chemical structure and organization. Efficient bioconversion of lignocellulosic biomass in to fermentable sugars requires cooperative action of various cellulolytic and hemicellulolytic enzymes at appropriate levels [5]. Moreover, concentration of fermentable sugars should be high enough in enzymatic hydrolysate as at least $4 \%$ ethanol concentration is required to develop an economically viable distillation process [6]. Considering economic viability, high gravity ethanol fermentations are attempted at high sugar concentrations [7].

Another challenging aspect in bioethanol technology is bioconversion of hexoses and pentoses both to ethanol [8]. Unfortunately, there are limited microorganisms that can proficiently convert both of these sugars to ethanol. Saccharomyces cerevisiae and Zymomonas mobilis have been reported for the glucose conversion while Pichia stipitis, Candida shehatae and Pachysolen tannophilus have been reported for the xylose conversion [9]. Various recombinant yeasts and bacteria have been developed during the last few decades that can ferment both the sugars [10]. However, their use for largescale industrial processes still needs improvements related to the stability of the entire process and to overcome the public concerns for recombinant microorganisms [11,12]. Attempts have been made to utilize both hexoses and pentoses by co-culturing of Saccharomyces cerevisiae and Pichia stipitis [13]. However, co-cultures of these yeasts do not always ensure the efficient xylose conversion which may be because of diauxic behavior of xylose-fermenting yeasts, inhibition by ethanol and oxygen competition between the xylose fermenters and glucose fermenters [14]. Generally microorganisms consume glucose over galactose followed by xylose and arabinose [15]. In co-culture process if fermentation time is not sufficiently long, pentoses remain unutilized in the medium. Hence to overcome the problems of coculturing, sequential glucose fermentation by Saccharomyces cerevisiae and xylose fermentation by Pichia stipitis can be a logical approach Such a strategy can help to overcome glucose repression, ethanol inhibition and oxygen competition on xylose fermenting Pichia stipitis. Sequential ethanol fermentation processes using hexose and pentose fermenting yeasts have been reported [15-17].

We have already optimized saccharification of mild alkali treated maize stover using cocktail of in-house produced hemicellulases supplemented with commercial cellulases. This cocktail was effective at high substrate loading and preliminary experiments on ethanol production from enzymatic hydrolysate of maize stover by Saccharomyces cerevisiae 3524, yielded maximum $7.68 \mathrm{~g} / \mathrm{l}$ ethanol at $3 \%$ reducing sugar concentration. In order to generate high concentration of ethanol, the present study was aimed at optimization of ethanol fermentation process using response surface methodology. In addition the research attempted sequential fermentation of hexoses followed by pentoses using Saccharomyces cerevisiae and Pichia stipitis respectively.

\section{Materials and Methods}

\section{Materials}

Throughout the research work analytical grade chemicals, media and reagents were used and were purchased from Qualigens, Hi-media, Merck, Loba from India. P-nitrophenyl- $\beta$-Dxylopyranoside $P$-nitrophenyl- $\alpha$-L-arabinofuranoside, $P$-nitrophenyl-

*Corresponding author: Amita Shah, BRD School of Biosciences, Sardar Patel Maidan, Satellite Campus, P Box No. 39, Sardar Patel University, Vallabh Vidyanagar-388 120, Gujarat, India, Tel: +912692234412 extn. 114; Fax: +912692231042; E-mail: arshah02@yahoo.com

Received March 11, 2016; Accepted March 31, 2016; Published April 07, 2016

Citation: Patel H, Divecha J, Shah A (2016) Optimization of Ethanol Production from Enzymatic Hydrolysate of Maize Stover. Adv Recycling Waste Manag 1: 106. DOI: $10.4172 / 2475-7675.1000106$

Copyright: (C) 2016 Patel $\mathrm{H}$, et al. This is an open-access article distributed under the terms of the Creative Commons Attribution License, which permits unrestricted use, distribution, and reproduction in any medium, provided the original author and source are credited. 
$\beta$-D-glucopyranoside and Ethyl ferlulate (Ethyl 4-hydroxy-3methoxycinnamate) were obtained from Sigma-Aldrich, USA. Maps Enzyme Limited, India provided commercial cellulase MAPs 450.

\section{Maize stover}

Maize stover was obtained from local farmer from Panchmahal district, Gujarat. Maize stover was cut to $5 \mathrm{~mm}$ length, washed with tap water, air-dried and stored in air tight plastic bag at room temperature.

\section{Microbial strains}

For production of hemicellulases under solid state fermentation, Aspergillus niger ADH-11 (Accession no KF026012) was used. While for ethanol production standard yeast cultures, Sacchromyces cerevisiae NCIM 3524 and Pichia stipitis NCIM 3497 were procured from NCIM, Pune, India.

\section{Enzymes}

Crude $\beta$-xylosidase rich hemicellulases was indigenously produced by Aspergillus niger ADH-11 under solid state fermentation using previously optimized conditions [18]. Commercial cellulase was kindly provided by MAPS Enzymes Private Ltd., Gujarat, India. Enzyme doses were used as per necessity in the experiment. The crude $\beta$-xylosidase enzyme from Aspergillus niger ADH-11 and commercial cellulase (MAPs 450), were also having other cellulolytic and xylanolytic enzymes (Table 1).

\section{Enzyme assays}

$\beta$-Xylosidase activity was determined by quantifying $p$-nitrophenol release from $p$-nitrophenyl- $\beta$-D-xylopyranoside at $50^{\circ} \mathrm{C}$. The reaction mixture containing of $2 \mathrm{mM} p$-nitrophenyl- $\beta$-D-xylopyranoside in $50 \mathrm{mM}$ sodium citrate buffer $(\mathrm{pH} 5.3)$ was incubated with enzyme at $50^{\circ} \mathrm{C}$ for $30 \mathrm{~min}$ in a total volume of $0.5 \mathrm{ml}$. The reaction was ended by adding $1 \mathrm{ml}$ of $2 \mathrm{M}$ sodium carbonate. The amount of released $p$-nitrophenol was determined by measuring absorbance at $410 \mathrm{~nm}$. One unit of $\beta$-xylosidase activity is defined as amount of enzyme required to release $1 \mu \mathrm{M}$ of $p$-nitrophenol per minute under assay condition. $\alpha$-L-Arabinofuranosidase activity was determined by measuring $p$-nitrophenol release from $p$-nitrophenyl- $\alpha$-Larabinofuranoside at $50^{\circ} \mathrm{C}$. The reaction mixture consisting of $1 \mathrm{mM}$ $p$-nitrophenyl- $\alpha$-L-arabinofuranoside in $50 \mathrm{mM}$ sodium citrate buffer (pH 5.3) was incubated with enzyme at $50^{\circ} \mathrm{C}$ for $10 \mathrm{~min}$ in total volume of $0.5 \mathrm{ml}$. The reaction was terminated by adding $1 \mathrm{ml}$ of $2 \mathrm{M}$ sodium carbonate. The amount of $p$-nitrophenol released was determined by measuring absorbance at $410 \mathrm{~nm}$. One unit of $\alpha$-L-arabinofuranosidase activity is defined as amount of enzyme required to release $1 \mu \mathrm{M}$ of $p$-nitrophenol per minute under assay condition. Xylanase activity was determined using birch wood xylan solution (1\%) as a substrate [19]. The substrate was prepared in $50 \mathrm{mM}$ sodium citrate buffer $(\mathrm{pH}$ 5.3). The enzyme reaction was carried out for $10 \mathrm{~min}$ at $50^{\circ} \mathrm{C}$ and was ended by adding $1 \mathrm{ml}$ of DNS reagent. The xylanase activity was determined by quantifying the release of reducing sugar using xylose as standard [20]. One unit of xylanase activity is defined as amount of enzyme required to release $1 \mu \mathrm{M}$ of xylose per minute under assay condition. According to the IUPAC recommendation, Filter paper activity was measured using Whatmann filter paper no. 1 as a substrate [21]. The reducing sugars, release after $60 \mathrm{~min}$ in $50^{\circ} \mathrm{C}$, at $\mathrm{pH} 4.8(50$ $\mathrm{mM}$ sodium citrate buffer) was measured as glucose equivalent by DNS method. One unit of filter paper activity is defined as amount of enzyme required to release $1 \mu \mathrm{M}$ of glucose per minute under assay condition. Endo-glucanase activity was determined by measuring reducing sugars release from carboxymethylcellulose (CMC) at $55^{\circ} \mathrm{C}$. The reaction mixture consisting of $2 \%$ carboxymethylcellulose in 50 $\mathrm{mM}$ sodium citrate buffer ( $\mathrm{pH} 4.8)$ was incubated with enzyme at $55^{\circ} \mathrm{C}$ for $30 \mathrm{~min}$ in total volume of $1.0 \mathrm{ml}$. The reaction was terminated by adding $1 \mathrm{ml}$ of DNS reagent. The enzyme activity was determined by measuring the release of reducing sugar using glucose as standard. One unit of endo-glucanase activity is defined as amount of enzyme required to release $1 \mu \mathrm{M}$ of glucose per minute under assay condition. $\beta$-Glucosidase activity was determined by measuring $p$-nitrophenol release from $p$-nitrophenyl- $\beta$-D-glucopyranoside at $50^{\circ} \mathrm{C}$. The reaction mixture consisting of $2 \mathrm{mM} p$-nitrophenyl- $\beta$ - $\mathrm{D}$-glucopyranoside in 50 $\mathrm{mM}$ sodium citrate buffer $(\mathrm{pH} 4.8)$ was incubated with enzyme at $50^{\circ} \mathrm{C}$ for $30 \mathrm{~min}$ in total volume of $0.5 \mathrm{ml}$. The reaction was terminated by adding $1 \mathrm{ml}$ of $2 \mathrm{M}$ sodium carbonate. The amount of $p$-nitrophenol released was determined by measuring absorbance at $410 \mathrm{~nm}$. One unit of $\beta$-glucosidase activity is defined as amount of enzyme required to release $1 \mu \mathrm{M}$ of $p$-nitrophenol per minute under assay condition. Feruloyl esterase activity was determined by measuring ferulic acid release from ethyl ferlulate (Ethyl 4-hydroxy-3-methoxycinnamate) at $50^{\circ} \mathrm{C}$. The reaction mixture consists of $2 \mathrm{mM}$ ethyl ferulate in $50 \mathrm{mM}$ sodium citrate buffer ( $\mathrm{pH} \mathrm{5.3)} \mathrm{was} \mathrm{incubated} \mathrm{with} \mathrm{enzyme} \mathrm{at} 50^{\circ} \mathrm{C}$ for $30 \mathrm{~min}$ in total volume of $1.0 \mathrm{ml}$. The reaction was terminated by heating in boiling water bath for $10 \mathrm{~min}$. The amount of ferulic acid released was determined by HPLC using ferulic acid as standard. One unit of feruloyl esterase activity is defined as amount of enzyme required to release $1 \mu \mathrm{M}$ of ferulic acid per minute under assay condition.

\section{Maize stover pretreatment}

Pretreatment of maize stover was carried out by soaking maize stover in $2 \% \mathrm{NaOH}$ solution $(10 \%$ slurry $(\mathrm{w} / \mathrm{v}))$ at $30^{\circ} \mathrm{C}$ for $12 \mathrm{~h}$. The substrate was neutralized with $12 \mathrm{~N} \mathrm{HCl}$, filtered with wet muslin cloth and then dried in oven at $80^{\circ} \mathrm{C}$. Using Goering and Van Soest [22] method, composition (cellulose, hemicellulose and lignin) of untreated and pretreated maize stover were determined.

\section{Enzymatic saccharification of pretreated maize stover at high substrate loading using cocktail of crude $\boldsymbol{\beta}$-xylosidase and commercial cellulase (MAPs 450)}

Maize stover saccharification was carried out using $13 \mathrm{FPU} / \mathrm{g}$ commercial cellulase (MAPs 450) supplemented with $74.42 \mathrm{U} / \mathrm{g}$ inhouse produced $\beta$-xylosidase rich crude enzyme from Aspergillus niger $\mathrm{ADH}-11$. Enzymatic sacccharification was carried out in $250 \mathrm{ml}$ plastic bottle containing $30 \%$ pretreated maize stover and diluted enzyme in $50 \mathrm{mM}$ sodium citrate buffer ( $\mathrm{pH} 4.8$ ) having $0.1 \%$ Tween- 80 (v/v) in a total volume of $40 \mathrm{ml}$. Controls were taken for each reaction in which the active enzyme was substituted with heat inactivated enzyme. The reaction system was fortified with $10 \mathrm{mg} \%$ sodium azide. The reaction was performed at $50^{\circ} \mathrm{C}$ in hybridization oven at $100 \mathrm{rpm}$. After $36 \mathrm{~h}$,

\begin{tabular}{|c|c|c|c|c|c|c|c|}
\hline Enzyme & $\begin{array}{c}\beta-X y l o s i d a s e \\
\left(U \mathrm{ml}^{-1}\right)\end{array}$ & 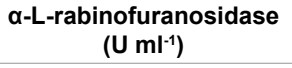 & $\begin{array}{l}\text { Feruloyl esterase } \\
\qquad\left(\mathrm{U} \mathrm{ml^{-1 } )}\right.\end{array}$ & $\begin{array}{c}\text { Xylanase } \\
\left(\mathrm{U} \mathrm{\textrm {ml } ^ { - 1 } )}\right.\end{array}$ & $\begin{array}{l}\text { Filter paper activity } \\
\left(\left(\mathrm{U} \mathrm{ml} \mathrm{ml}^{-1}\right)\right.\end{array}$ & $\begin{array}{l}\text { Endo-glucanase } \\
\qquad\left(\mathrm{U} \mathrm{ml}^{-1}\right)\end{array}$ & $\begin{array}{l}\beta \text {-Glucosidase } \\
\left(\mathrm{U} \mathrm{ml^{-1 } )}\right.\end{array}$ \\
\hline Crude $\beta$-xylosidase & 30.0 & 1.57 & 1.0 & 20.0 & 0.64 & 42.98 & 11.40 \\
\hline Commercial cellulase & ND & ND & ND & 300.0 & 43.9 & 2798.0 & 43.0 \\
\hline
\end{tabular}

ND: Not Detected 
samples were withdrawn and heated in boiling water bath $\left(100^{\circ} \mathrm{C}\right)$ for enzyme inactivation. Then filtered using wet muslin cloth by thorough squeezing followed by centrifuged to collect the clear supernatant, which was used for further analysis to estimate reducing sugars by DNS method [20] and glucose, xylose and arabinose by HPLC method.

\section{Optimization of ethanol production using hexose fermenting Saccharomyces cerevisiae NCIM 3524}

Inoculum was prepared using $12 \mathrm{~h}$ grown culture (Saccharomyces cerevisiae NCIM 3524$)$ at $30^{\circ} \mathrm{C}$ in a medium containing glucose (1\%), yeast extract $(0.3 \%)$, malt extract $(0.3 \%)$ and peptone $(0.5 \%)$ having $\mathrm{pH}$ $6.5 \pm 0.2$. The fermentation experiment was carried out in $50 \mathrm{ml} \mathrm{screw}$ cap tube at $30 \pm 2^{\circ} \mathrm{C}$ without agitation. The samples were centrifuged for $10 \mathrm{~min}$ at $4^{\circ} \mathrm{C}$ at $15,000 \mathrm{rpm}$, filtered using $0.2 \mu$ filter and analyzed using HPLC for the presence of sugars and ethanol.

BBD for optimization of ethanol fermentation from hexose sugar: A Box- Behnken factorial design with three factors and three levels was used for optimization of ethanol production. The independent variables were $\%$ glucose $\left(\mathrm{X}_{1}\right), \%$ inoculum $\left(\mathrm{X}_{2}\right)$ and time $\left(\mathrm{X}_{3}\right)$. Final ethanol yield $\left(\mathrm{g} \mathrm{g}^{-1}\right)$ was the dependent response variable. Selected independent variables were studied at three levels (Table 2) employing BBD with total 15 experimental runs (Table 3 ). The variables were taken at a central code value considered as zero. The temperature was kept constant at $30^{\circ} \mathrm{C}$ throughout the experiments runs.

Quadratic models considered as response surface model for predicting the optimal points were expressed according to Eq. (1) and (2).

For statistical calculations the independent variables were coded as: $\mathrm{X}_{\mathrm{i}}=\left(\mathrm{X}_{\mathrm{i}}-\mathrm{X}_{\mathrm{o}}\right) / \delta \mathrm{X}_{\mathrm{i}}$

Where $\mathrm{X}_{\mathrm{i}}$ is the experimental coded value of the variable; $\mathrm{X}_{\mathrm{o}}$ is the middle value of $\mathrm{X}_{\mathrm{i}}$ and $\delta \mathrm{X}_{\mathrm{i}}$ is the step change.

\begin{tabular}{|c|c|c|c|c|}
\hline \multirow{2}{*}{ Variable } & Symbols & \multicolumn{3}{|c|}{ Coded level of variable } \\
\cline { 2 - 5 } & & $-\mathbf{1}$ & $\mathbf{0}$ & $\mathbf{1}$ \\
\hline \% Glucose & $\mathrm{X}_{1}$ & 1 & 3 & 5 \\
\hline \% Inoculum & $\mathrm{X}_{2}$ & 5 & 10 & 15 \\
\hline Time $(\mathrm{h})$ & $\mathrm{X}_{3}$ & 12 & 24 & 36 \\
\hline
\end{tabular}

Table 2: Coded values and experimental range of process variables used in experimental design.

\begin{tabular}{|c|c|c|c|c|c|}
\hline Run & $\begin{array}{c}\text { Sugar } \\
\text { concentration } \\
\left(\mathbf{X}_{\mathbf{1}}\right)\end{array}$ & $\begin{array}{c}\text { Inoculum } \\
\text { size } \mathbf{(}_{\mathbf{2}} \mathbf{)}\end{array}$ & Time $\mathbf{X}_{\mathbf{3}} \mathbf{)}$ & \multicolumn{2}{|c|}{ Ethanol yield $\mathbf{g}^{-1} \mathbf{)}$} \\
\hline 1 & -1 & -1 & 0 & 0.33 & 0.34 \\
\hline 2 & -1 & 1 & 0 & 0.34 & 0.36 \\
\hline 3 & 1 & -1 & 0 & 0.11 & 0.14 \\
\hline 4 & 1 & 1 & 0 & 0.20 & 0.22 \\
\hline 5 & -1 & 0 & -1 & 0.38 & 0.36 \\
\hline 6 & -1 & 0 & 1 & 0.30 & 0.31 \\
\hline 7 & 1 & 0 & -1 & 0.08 & 0.07 \\
\hline 8 & 1 & 0 & 1 & 0.18 & 0.2 \\
\hline 9 & 0 & -1 & -1 & 0.15 & 0.16 \\
\hline 10 & 0 & -1 & 1 & 0.33 & 0.31 \\
\hline 11 & 0 & 1 & -1 & 0.26 & 0.24 \\
\hline 12 & 0 & 1 & 1 & 0.30 & 0.33 \\
\hline 13 & 0 & 0 & 0 & 0.28 & 0.29 \\
\hline 14 & 0 & 0 & 0 & 0.28 & 0.29 \\
\hline 15 & 0 & 0 & 0 & 0.29 & 0.31 \\
\hline
\end{tabular}

Table 3: Experimental plan and the results of the Box-Behnken design.
Ethanol yield (response Y) was explained as a second order response model on three independent variables given by

$$
\mathrm{Y}=\beta_{\mathrm{o}}+\Sigma \beta_{\mathrm{i}} \mathrm{X}_{\mathrm{i}}+\Sigma \beta_{\mathrm{ii}} \mathrm{X}_{\mathrm{i}}^{2}+\Sigma \beta_{\mathrm{ij}} \mathrm{X}_{\mathrm{i}} \mathrm{X}_{\mathrm{j}}
$$

Where $Y$ is the predicted response variable, $\beta_{\mathrm{o}}, \beta_{\mathrm{i},} \beta_{\mathrm{ii}}, \beta_{\mathrm{ij}}$ are fixed regression coefficients of the model, $x_{i}, x_{j}(i=1,2,3, i \neq j)$ represents independent variables in the form of original values.

\section{Interpretation and data analysis}

The experimental design results were evaluated and interpreted by MINITAB 16 (PA, USA) statistical software. Optimum fermentation parameters prediction and response contour plot created by the model was also evaluated by the same software. ANOVA was used to establish the significance of the model parameters.

\section{Recovery of ethanol from fermented broth}

Ethanol produced by hexose fermenting yeast was recovered using Rota-evaporator under vacuum at $45^{\circ} \mathrm{C}$ with $120 \mathrm{rpm}$ for $60 \mathrm{~min}$.

\section{Ethanol production using pentose fermenting Pichia stipitis NCIM 3497}

Ethanol fermentation using Pichia stipitis NCIM 3497 from fermented broth after distillation was carried out by preparing medium containing $0.3 \%(\mathrm{w} / \mathrm{v})$ yeast extract, $0.3 \%(\mathrm{w} / \mathrm{v})$ malt extract, $0.5 \%$ $(\mathrm{w} / \mathrm{v})$ peptone and adjusting xylose concentration at $1.58 \%$ with $\mathrm{pH}$ $6.5 \pm 0.2$. The medium was sterilized at $10 \mathrm{lbs}$ for $20 \mathrm{~min}$. After cooling the medium to $30^{\circ} \mathrm{C}$, it was inoculated aseptically with $5.40 \%(\mathrm{v} / \mathrm{v})$ of $24 \mathrm{~h}$ old culture inoculum (Pichia stipitis NCIM 3497 with Absorbance of 0.6 at $660 \mathrm{~nm}$ ). All the closed screw caps tubes were incubated at $30^{\circ} \mathrm{C}$ in static condition. The samples were withdrawn after $24 \mathrm{~h}$ and analyzed for ethanol production by HPLC and reducing sugars by DNS method [20].

\section{Analytical techniques}

Ferulic acid was analyzed using high performance liquid chromatography system (Shimadzu, Japan) equipped with photo diode detector (PDA) using a Luna $5 \mathrm{u} \mathrm{C18} \mathrm{(2)} \mathrm{column} \mathrm{with} \mathrm{dimension} \mathrm{of} 250$ $\mathrm{mm} \times 4.6 \mathrm{~mm}$. Samples were eluted using Water: Acetonitrile : Formic acid $(7: 2: 1)$ with the flow rate of $0.6 \mathrm{ml} \mathrm{min}^{-1}$. Column was kept at room temperature throughout analysis. Ferulic acid $\left(1 \mathrm{mg} \mathrm{ml}^{-1}\right)$ was used as the standards. Appropriately diluted samples were filtered through 0.2 $\mu$ filters to remove any residual debris before injecting in the column. Ferulic acid was quantified using average peak areas of standards.

Monosaccharide sugars were analyzed using high performance liquid chromatography system (Shimadzu, Japan) equipped with a refractive index detector (RID). Sugars were analyzed using a Phenomenex, Rezex ROA-Organic acid $\mathrm{H}+(8 \%)$ column with dimension of $300 \mathrm{~mm} \times 7.8 \mathrm{~mm}$. Samples were eluted using $5 \mathrm{mM}$ $\mathrm{H}_{2} \mathrm{SO}_{4}$ with the flow rate of $0.6 \mathrm{ml} \mathrm{min}^{-1}$. Column temperature was kept at $65^{\circ} \mathrm{C}$ throughout analysis. Glucose, xylose arabinose and ethanol were used as the standards. Appropriately diluted samples were filtered through $0.2 \mu$ filters to remove any residual debris before injecting in the column. Sugars and ethanol were quantified using average peak areas of standards.

\section{Results and Discussion}

Enzymatic hydrolysis of mild alkali treated maize stover using in-house produced hemicellulases supplemented with commercial cellulases was previously optimized in our laboratory at low substrate loading and the cocktail was also found effective at high substrate 
loading. In order to achieve higher ethanol concentration enzymatic hydrolysis of maize stover was carried out at 30\% substrate loading. Effective industrial production of bioethanol from maize stover requires utilization of both hexose and pentose sugars. Hence, the sequential ethanol fermentation was carried out for bioethanol production from enzymatic hydrolysate of maize stover.

Enzymatic saccharification of pretreated maize stover at high substrate loading using cocktail of crude $\beta$-xylosidase and commercial cellulase (MAPs 450)

Enzymatic saccharification at high substrate loading potentially offers many advantages. High substrate load have positive effect on economy of the process as it allows use of smaller reactor, produce concentrated sugar syrup and eventually lower distillation cost. The developed cocktail using in-house produced hemicellulases with commercial cellulases was used for saccharification of maize stover at high substrate loading (30\%). The result clearly showed that the cocktail was highly effective at high substrate loading and liquefaction of solid residues was observed after $36 \mathrm{~h}$ (Figure 1) which contained maximum $161.32 \mathrm{mg} \mathrm{ml}^{-1}$ reducing sugar. This sugar rich hydrolysate mainly contained $67.84 \mathrm{mg} \mathrm{ml}^{-1}$ glucose, $34.62 \mathrm{mg} \mathrm{ml}^{-1}$ xylose and $6.14 \mathrm{mg} \mathrm{ml}^{-1}$ arabinose. Such a concentrated sugar syrup is highly advantageous for commercial ethanol fermentation process as concentration step can be avoided.

\section{Optimization of ethanol production from hexose sugar using RSM}

Three variables viz. \% glucose, \% inoculum and time (h) were selected for response surface optimization and ethanol yield $\mathrm{g} \mathrm{g}^{-1}$ was selected as response variable. The results of all the experimental runs ( 15 run) are shown in Table 3 . The experimental results suggest that the variable used in the present study had strong effect on ethanol yield. On the basis of these experimental values, statistical testing was carried out using MINITAB 16. The analysis of the model was tested by Fisher's ' $F$ ' and Student's t-test. Analysis of variance (ANOVA) of ethanol yield showed that the model was significant $(\mathrm{P}=0.002)$ as shown in Table 5, mainly due to the square portion of the regression model. A P-value below 0.05 indicates the test parameter are significant.

The fitted second-order response surface model as specified by Equation 2 for ethanol yield in coded process variables is as follows:

$\mathrm{Y}=0.419688-0.081875 \mathrm{x}_{1}+0.029750 \mathrm{x}_{2}+0.001146 \mathrm{x}_{3}-0.006562 \mathrm{x}_{1}{ }^{2}$ $0.001450 \mathrm{x}_{2}^{2}-0.000043 \mathrm{x}_{3}^{2}+0.003250 \mathrm{x}_{1} \mathrm{x}_{2}+0.001563 \mathrm{x}_{1} \mathrm{x}_{3}-0.000208 \mathrm{x}_{2} \mathrm{x}_{3}(3)$

Where, $\mathrm{Y}$ is ethanol yield, and $\mathrm{x}_{1}, \mathrm{x}_{2}$ and $\mathrm{x}_{3}$ are uncoded values of $\%$ glucose, $\%$ inoculum and Time h, respectively. A comparison of the experimentally obtained values with the predicted values indicated that these data are in reasonable agreement as shown in Table 3. The parameter estimates and the corresponding P-value showed that selected variable \% glucose and \% inoculum had significant square effect (0.024 and 0.052) on ethanol yield (Tables 4 and 5). Also interaction between $\%$ glucose and \% inoculum, \% glucose and time and $\%$ inoculum and time had significant square effect $(0.042,0.026$ and 0.043 ) on ethanol yield (Table 4 ). The $\mathrm{R}^{2}$ value provides a measure of variability in the observed response values that can be explained by the experimental factors and their interactions. Joglekar and May [23] have suggested that for a good fit of the model, $\mathrm{R}^{2}$ should be at least $80 \%$. Coefficient $\mathrm{R}^{2}$ for reducing sugar yield was observed to be $97.5 \%$.

Application of RSM by Box-Behnken design, predicted that maximum ethanol yield occurred at values of process parameters as $5 \%$ glucose, $14.55 \%$ inoculum and Time $35.51 \mathrm{~h}$. The model predicted highest (optimum) ethanol yield was $0.364 \mathrm{~g} \mathrm{~g}^{-1}$ (Figure 2).

\section{Validation of the experimental model}

A repeat fermentation for ethanol production from hexoses using Saccharomyces cerevisiae NCIM 3524 under optimal conditions was carried out for the validation of optimized parameters. The enzymatic hydrolysate was effectively utilized by hexose fermenting yeast and under optimized condition $90.65 \%$ glucose was utilized. Ethanol yield was $0.374 \mathrm{~g} \mathrm{~g}^{-1}\left(18.93 \mathrm{mg} \mathrm{ml}^{-1}\right.$ ) with $0.53 \mathrm{~g} \mathrm{l}^{-1} \mathrm{~h}^{-1}$ productivity (Table 6). Before optimization, ethanol yield was only $7.68 \mathrm{mg} \mathrm{ml}^{-1}$ at $3 \%$ total reducing sugars which contained only $1.2 \%$ glucose. By applying response surface methodology ethanol production was enhanced up to 2.46 fold at high sugar concentration ( $9 \%$ total reducing sugars which contained 5\% glucose).

In current scenario, cost-competitive ligno-cellulosic biofuel production can be intended by operating the process at high gravity [7]. Li et al. reported maximum $11.8 \mathrm{mg} \mathrm{ml}^{-1}$ ethanol production with $0.110 \mathrm{~g} \mathrm{l}^{-1} \mathrm{~h}^{-1}$ productivity using Saccharomyces cerevisiae [17]. As compared to this, the productivity of the ethanol from hexose sugar in the present study was higher. A comparison of ethanol production by Saccharomycere cerevisiae from various lignocellulosic biomass is shown in Table 7. It can be seen that in the present study ethanol concentration is comparable or even higher as compared to other reports.

\begin{tabular}{|c|c|c|c|c|}
\hline Term & Coef & SE Coef & T & P \\
\hline Constant & 0.419688 & 0.101719 & 4.126 & 0.009 \\
\hline \% Glucose & -0.081875 & 0.025498 & -3.211 & 0.024 \\
\hline \% Inoculum & 0.029750 & 0.011716 & 2.539 & 0.052 \\
\hline Time & 0.001146 & 0.004882 & 0.235 & 0.824 \\
\hline \% Glucose X \% Glucose & -0.006562 & 0.003106 & -2.113 & 0.088 \\
\hline \% Inoculum X \% Inoculum & -0.001450 & 0.000497 & -2.918 & 0.033 \\
\hline Time X Time & -0.000043 & 0.000086 & -0.503 & 0.636 \\
\hline \% Glucose X \% Inoculum & 0.003250 & 0.001194 & 2.723 & 0.042 \\
\hline \% Glucose X Time & 0.001563 & 0.000497 & 3.141 & 0.026 \\
\hline \% Inoculum X Time & -0.000208 & 0.000199 & -1.047 & 0.043 \\
\hline
\end{tabular}

Table 4: Regression coefficients for ethanol yield $\mathrm{g} \mathrm{g}^{-1}$.

\begin{tabular}{|c|c|c|c|c|c|c|}
\hline Source & DF & Seq SS & Adj SS & Adj MS & F & P \\
\hline Regression & 9 & 0.110683 & 0.110683 & 0.011298 & 21.58 & 0.002 \\
\hline Linear & 3 & 0.093300 & 0.011789 & 0.003930 & 6.89 & 0.032 \\
\hline Square & 3 & 0.006908 & 0.006908 & 0.002303 & 4.04 & 0.083 \\
\hline Interaction & 3 & 0.010475 & 0.010475 & 0.003492 & 6.13 & 0.040 \\
\hline Residual Error & 5 & 0.002850 & 0.002850 & 0.000570 & & \\
\hline Lack-of-Fit & 3 & 0.002650 & 0.002650 & 0.000883 & 8.83 & 0.103 \\
\hline Pure Error & 2 & 0.000200 & 0.000200 & 0.000100 & & \\
\hline Total & 14 & 0.113533 & & & & \\
\hline
\end{tabular}

Table 5: Analysis of variance for ethanol yield $\mathrm{g} \mathrm{g}^{-1}$.

\begin{tabular}{|c|c|}
\hline Parameters & \\
\hline Initial reducing sugar $\left(\mathrm{g} \mathrm{l}^{-1}\right)$ & 90.0 \\
\hline Initial glucose $\left(\mathrm{g} \mathrm{l}^{-1}\right)$ & 50.0 \\
\hline Ethanol $\left(\mathrm{g} \mathrm{l}^{-1}\right)$ & 18.93 \\
\hline$\%$ Reducing sugar consumed & $55.55 \%$ \\
\hline$\%$ Glucose consumed & $90.65 \%$ \\
\hline Ethanol yield $\mathrm{g} \mathrm{g}^{-1}$ glucose & 0.374 \\
\hline Ethanol yield $\mathrm{g} \mathrm{g}^{-1}$ consumed reducing sugar & 0.378 \\
\hline Productivity $\left(\mathrm{g} \mathrm{l}^{-1} \mathrm{~h}^{-1}\right)$ & 0.53 \\
\hline
\end{tabular}

Table 6: Ethanol fermentation from enzymatic hydrolysate of maize stover by Saccharomycere cerevisiae under optimized conditions. 
Citation: Patel H, Divecha J, Shah A (2016) Optimization of Ethanol Production from Enzymatic Hydrolysate of Maize Stover. Adv Recycling Waste Manag 1: 106.DOI: 10.4172/2475-7675.1000106

Page 5 of 6

\begin{tabular}{|c|c|c|c|c|}
\hline Lignocellulosic Biomass & Fermentation condition & $\begin{array}{l}\text { Ethanol concentration } \\
(\mathrm{mg} / \mathrm{ml})\end{array}$ & $\begin{array}{l}\text { Ethanol Yield } \\
(\mathrm{g} / \mathrm{g})\end{array}$ & Reference \\
\hline Wheat straw & Reducing sugar $6.5 \%$, inoculum $3.3 \%$ at $30^{\circ} \mathrm{C}, 36 \mathrm{~h}$ & 15.6 & 0.480 & [25] \\
\hline Rice straw & Reducing sugar $6 \%$, inoculum $10 \%$ at $28^{\circ} \mathrm{C}, 24 \mathrm{~h}$ & 12.34 & 0.093 & [26] \\
\hline Sweet sorghum & Sorghum juice, containing $19.9 \%$ sucrose and $1.9 \%(w / w)$ glucose at $33^{\circ} \mathrm{C}, 24 \mathrm{~h}$ & - & 0.400 & [27] \\
\hline Corn cobs & $95.3 \mathrm{~g} \mathrm{l}^{-1}$ glucose, $5 \mathrm{~g} \mathrm{l}^{-1}$ peptone, $3 \mathrm{~g} \mathrm{l}^{-1}$ yeast extract at $30^{\circ} \mathrm{C}, 24 \mathrm{~h}$ & 45.7 & 0.480 & [28] \\
\hline Maize stover & $50 \mathrm{~g} \mathrm{l}^{-1}$ glucose (90 $\mathrm{g} \mathrm{l}^{-1}$ reducing sugars), $14.55 \%$ inoculum at $30^{\circ} \mathrm{C}, 35.51 \mathrm{~h}$ & 18.93 & 0.374 & Present study \\
\hline
\end{tabular}

Table 7: Ethanol yield from various lignocellulosic biomass by Saccharomycere cerevisiae.

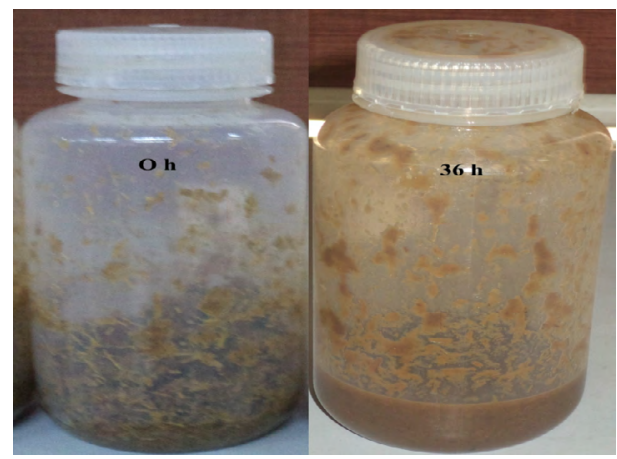

Figure 1: Liquefaction of solid residues at high substrate loading $(30 \%)$ using developed cocktail of $74.42 \mathrm{U} / \mathrm{g}$ crude $\beta$-xylosidase and $13 \mathrm{FPU} / \mathrm{g}$ commercial cellulase at $50^{\circ} \mathrm{C}$ after $36 \mathrm{~h}$.

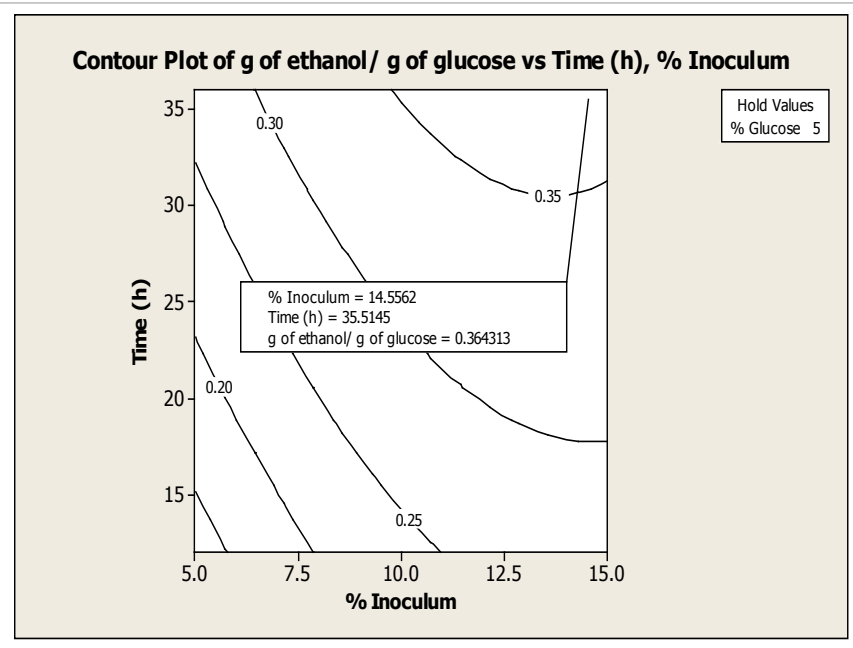

Figure 2: Contour plot showing interaction effect of \% inoculum and time on ethanol yield $(\mathrm{g} / \mathrm{g})$ at hold value of $\%$ glucose.

\section{Ethanol production by Pichia stipitis NCIM 3497}

After ethanol recovery, hydrolysate mainly contained xylose, hence ethanol production using Pichia stipitis NCIM 3497 was carried out and only $71 \%$ xylose was utilized by yeast with maximum ethanol yield of $0.38 \mathrm{~g} \mathrm{~g}^{-1}\left(2.23 \mathrm{mg} \mathrm{ml}^{-1}\right)$ with productivity $0.09 \mathrm{~g} \mathrm{l}^{-1} \mathrm{~h}^{-1}$. Agbogbo and Wenger [24] reported that Pichia stipitis produced ethanol yield $0.37 \mathrm{~g} \mathrm{~g}^{-1}\left(10.4 \mathrm{mg} \mathrm{ml}^{-1}\right)$ from enzymatic hydrolysate of corn stover. In the current investigation it was observed that production of ethanol from the remaining pentose sugar was lesser which may be due to existence of fermentative inhibitors produced by the hexose utilizing yeast. Hence, further studies are needed for effective utilization of pentose sugars.

\section{Conclusion}

It can be concluded from the present study that enzymatic hydrolysate obtained after saccharification of maize stover at high substrate loading was effectively utilized by Saccharomyces cerevisiae. By statistical optimization of ethanol fermentation process, production was enhanced up to 2.46 fold and ethanol concentration reached to $18.93 \mathrm{mg} \mathrm{ml}^{-1}$. However utilization of pentoses by sequential fermentation was not so effective. Hence, further studies are needed to increase ethanol production from pentoses.

\section{Acknowledgements}

Authors gratefully acknowledge Department of Biotechnology (DBT), New Delhi, India and Gujarat State Biotechnology Mission (GSBTM), Gandhinagar Gujarat, India for providing the research grants to support this work and also thankful to MAPs Enzyme Limited, India for providing cellulase enzyme.

\section{References}

1. Bondesson PM, Galbe M, Zacchi G (2013) Ethanol and biogas production after steam pretreatment of corn stover with or without the addition of sulphuric acid. Biotechnol Biofuels 6: 11

2. Dalgaard T, Jorgensen U, Olesen JE, Jensen ES, Kristensen ES (2006) Looking at biofuels and bioenergy. Science. 312: 1743-11743.

3. Wyman CE (1999) Biomass ethanol: technical progress, opportunities and commercial challenges. Annu Rev Energy Environ 24: 189-226.

4. Chen SF, Mowery RA, Scarlata CJ, Chambliss CK (2007) Compositional analysis of water-soluble materials in corn stover. J Agri Food Chem 55: 59125918.

5. Patel H, Chapla D, Divecha J, Shah A (2015) Improved yield of $\alpha-L$ arabinofuranosidase by newly isolated Aspergillus niger $\mathrm{ADH}-11$ and synergistic effect of crude enzyme on saccharification of maize stover. Bioresour Bioproces 2: 11.

6. Kristensen JB, Felby C, Jørgensen $H$ (2009) Yield-determining factors in highsolids enzymatic hydrolysis of lignocellulose. Biotechnol Biofuels 2: 11.

7. Bai FW, Zhao XQ (2012) High gravity ethanol fermentation and yeast tolerance. Microbial Stress Tolerance for Biofuels, Microbiology Monographs 22: 117-135.

8. Chen YF, Dong BY, Qin WJ, Xiao DG (2010) Xylose and cellulose fractionation from corncobs with three different strategies and separate fermentation of them to ethanol. Bioresour Technol 101: 6994-6999.

9. Fu N, Peiris P (2008) Co-fermentation of a mixture of glucose and xylose to ethanol by Zymomonas mobilis and Pachysolen tannophilus, W J Microbiol. Biotechnol 24: 1091-1097.

10. Saha BC, Cotta MA (2011) Continuous ethanol production from wheat straw hydrolysate by recombinant ethanologenic Escherichia coli strain FBR5. Appl Microbiol Biotechnol 90: 477-487.

11. Bothast RJ, Nichols NN, Dien BS (1999) Fermentations with new recombinant organisms, Biotechnol. Prog. 15: 867-875.

12. Dröge M, Pühler A, Selbitschka W (1998) Horizontal gene transfer as biosafety issue: a natural phenomenon of public concern. J Biotechnol 64: 7590.

13. Rouhollah H, Iraj N, Giti E, Sorah A (2007) Mixed sugar fermentation by Pichia stipitis, Saccharomyces cerevisiae and an isolated xylose fermenting Kluyveromyces marxinus and their co-culture. Afr J Biotechnol 6: 1110-1114.

14. De Bari I, Cuna D, Nanna F, Braccio G (2004) Ethanol production in immobilizedcell bioreactors from mixed sugar syrups and enzymatic hydrolysates of steamexploded biomass. Appl Biochem Biotechnol 114: 539-557. 
Citation: Patel H, Divecha J, Shah A (2016) Optimization of Ethanol Production from Enzymatic Hydrolysate of Maize Stover. Adv Recycling Waste Manag 1: 106.DOI: 10.4172/2475-7675.1000106

15. Gong CS, Cao NJ, Du J, Tsao GT (1999) Ethanol production from renewable resources. Adv Biochem. Eng/Biotechnol 65: 207-241.

16. Grootjen DRJ, van der Lans RGJM, Luyben KC (1990) Effect of the aeration rate on the fermentation of glucose and xylose by Pichia stipitis CBS 5773. Enzyme Microb Technol 12: 20-23.

17. Li Y, Park JY, Shiroma R, Tokuyasu K (2011) Bioethanol production from rice straw by a sequential use of Saccharomyces cerevisiae and Pichia stipitis with heat inactivation of Saccharomyces cerevisiae cells prior to xylose fermentation. J Biosci Bioeng 111: 682-686.

18. Patel H, Divecha J, Shah A (2016) Enhanced production of $\beta$-xylosidase from Aspergillus niger ADH-11 and development of synergistic enzyme cocktail for saccharification of sugarcane bagasse. Curr Biotechnol 5: 1-15.

19. Bailey MJ, Biely P, Poutanen K (1992) Interlaboratory testing of methods for assay of xylanase activity. J Biotechnol 23: 257-270.

20. Miller GL (1959) Use of dinitrosalicylic acid reagent for determination of reducing sugar. Anal Chem 31: 426-428.

21. Ghosh T (1994) Measurement of cellulase activities, Commission on Biotechnology. IUPAC, pp: 1-12.
22. Goering HK, Van Soest PJ (1970) Forage fiber analysis (Apparatus, Reagent, Procedure and Some application). Agricultural Handbook no. 379, Agricultural Research Service-United States Department of Agricultural. USDA, Washington DC, pp: 1-20.

23. Joglekar AM, May AT (1987) Product excellence through design of experiments. Cereal Foods World 32: 857-868.

24. Agbogbo FK, Wenger KS (2007) Production of ethanol from corn stover hemicellulose hydrolysate using Pichia stipitis. J Ind Microbiol Biotechnol 34: 723-727.

25. Singh A, Bishnoi NR (2013) Ethanol production from pretreated wheat straw hydrolysate by Saccharomyces cerevisiae vie sequential statistical optimization. Ind Crop Prod 41: 221-226.

26. Sukumaran RK, Singhania RR, Mathew GM, Pandey A (2009) Cellulase production using biomass feed stock and its application in lignocellulose saccharification for bio-ethanol production. Renew Energy 34: 421-424.

27. Mamma D, Christakopoulos P, Koullas D, Kekos D, Macris BJ, et al. (1995) An alternative approach to the bioconversion of sweet sorghum carbohydrates to ethanol Biomass Bioenergy 8: 99-103.

28. Chen M, Xia L, Xue P (2007) Enzymatic hydrolysis of corncob and ethano production from cellulosic hydrolyzate. Int Biodeterio Biodeg 59: 85-89. 